\title{
2.5D open source modeling of rock aggregate resources in the Helsinki metropolitan area
}

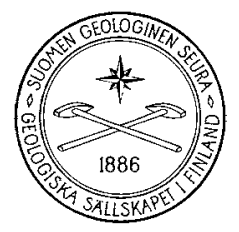

VERTAISARVIOITU KOLLEGIALT GRANSKAD PEER-REVIEWED
www.tsv.fi/tunnus

\author{
SAMPPA MäKELÄ \\ Department of Geosciences and Geography, University of Helsinki, P.O. Box 64, \\ FI-00014, Finland
}

\section{Abstract}

The objective of this study is to develop a method of appraising rock aggregate resources, using open data and open source tools. The availability of aggregates in Finland is mostly determined by competing land use and restrictions on extraction. Therefore, it is important to determine the extent of available resources, especially near areas of high demand.

The study area consists of the 14 municipalities in the Helsinki metropolitan area, a total of $3841 \mathrm{~km}^{2}$. The data used are open access, provided by the Geological Survey of Finland and the National Land Survey. These are combined in a GIS to identify locations where extraction of aggregates is possible. Geology, limitations and the highest and lowest point of possible extraction are determined. These are used to estimate the available resources and locate the economically feasible sites. Data used include a digital elevation model and layers on geology and land use.

The results show that competing land use has sterilized most aggregate locations in the area. Remaining locations are concentrated on the edges. However, some potential sites remain. Field evaluations and comparison to previous studies show that the method has potential in evaluating remaining resources and directing further study for prospective production areas.

The model is fast in coarsely determining aggregate volume. It is highly suitable for focusing expert fieldwork. Land use in the area continues to sterilize new locations. To avoid economic and ecological damage, a plan should be implemented for securing this resource. This may include the reserving of locations, reducing use, checking legislation on production and recycling used aggregates.

Keywords: rock aggregates, GIS, modeling, 2.5D, open data, open source, urban geology author e-mail: samppa.o.makela@gmail.com

Editorial handling: Jussi S. Heinonen (jussi.s.heinonen@helsinki.fi) 


\section{Introduction and previous studies}

Civilization relies on infrastructure for transportation, commerce and the free movement of people. When urban areas are increasing in size, population and density, the demand for materials of both infrastructure and construction increase. Aggregates are by volume the largest bulk material for all building projects, and thus their reliable supply is key for continued development. However, as urban land use prevents the extraction of aggregates, their availability is reduced. Thus, planners and developers need tools for ensuring the continued availability of this key resource. The objective in this study is to develop a method for locating and evaluating the amount of available rock aggregate resources using open source geographical information systems (GIS).

Aggregates are particles of rock, which, when brought together in a bound or unbound condition, form part or the whole of an engineering or building structure (Smith \& Collis, 1993). As a bulk commodity, aggregates are high in volume and low in price. Generally, aggregates are either dug from unconsolidated sand and gravel formations or are quarried and crushed from whole rock. As Finland has a high amount of glaciofluvial formations, most aggregates have traditionally been extracted as sand and gravel. Such formations are finite and also valued as fresh groundwater sources, recreational areas or for other uses (Britschgi, 2001; Räisänen, 2004; Lonka et al., 2015); Due to these factors and the increased demand for aggregates, rock aggregate quarries have been increasingly important sources especially near areas of high demand (Rintala, 2003; Räisänen, 2004; Lonka et al., 2015). The higher cost of rock aggregate extraction and processing is greatly offset by shorter transportation distances (Brown, 2012; Lonka et al., 2015).

Mapping aggregate resources is an excercise which must take several factors into consideration, including social, environmental and economical issues as well as problems of preservation versus developement (Ross \& Bobrowsky, 2002). Land use in areas of high population density is also a factor in aggregate production. Sources of aggregate may be sterilized by other forms of land use (Bobrowsky \& Manson, 1998; Brown, 2012; Dahl et al., 2012). Thus the available resources of aggregate are diminished, especially near the areas where the demand is highest. An estimation of available resources is valuable for planning, as far-sighted planners will avoid sterilizing all aggregates in order to minimize construction costs.

Aggregate quality is another consideration in their use. While it is of importance in demanding construction projects such as railroad ballast, its occurrence is not a simple thing to predict (Räisänen, 2004; Räisänen \& Torppa, 2005; Erichsen et al., 2008). Depending on local rock type, metamorphic conditions and even metasomatic changes in the rock, high-quality aggregates may be found in various locations and lithologies in Finland, and no single characteristic is foremost in predicting their occurrence. High-quality aggregates may be discovered in any host rock on a small scale, and require close field studies to separate from the more common but generally usable rock. Therefore, this study focuses on quantifying all potential aggregate sites and leaves the discovery of high-quality aggregates to the individual site studies which are necessary in every project.

Worldwide, rock aggregate availability has been previously studied with GIS methods (e.g., Baek et al., 2003; Robinson et al., 2004; Robinson \& Larkins, 2007; Karakaş, 2014) These methods have commonly placed focus on the suitability of the source rock, usually in priority to availability and location due to the prevalence of unsuitable rock types. Since most of the Finnish bedrock (especially in the Helsinki area) consists of plutonic and high-grade metamorphic rocks (Härme, 1980; Laitala, 1991; Grönholm, 2000a, 2000b; Vuokko, 2004), the quality of the rock itself is not as great a concern as it would be in a more heterogeneous location. In Finland, most research has been conducted as field studies, and has been based on expert evaluation of the available rocks (Grönholm, 
2000a, 2000b; Vuokko, 2004; Räisänen \& Torppa, 2005; Appelqvist et al., 2015). GIS methods may provide a useful approach to survey prospective rock aggregate production areas.

Aggregate resources are widespread, but their use is limited by various factors, including legislation, competing land-use, transportation distance, quality and environmental considerations. These questions have been studied previously (e.g., Ross \& Bobrowsky, 2002; Brown, 2012) They are required in most construction projects, especially in infrastructure. A model for their appraisal is needed because many of the limiting factors change rapidly and expert evaluation is constrained by time and resources. A model for the quantification of rock aggregates benefits both all stakeholders, and it is valuable for further inquiry into other similar resources as well.

The objective of this study is to introduce a method of using open access data to estimate the amount of recoverable rock aggregate reserves. This method uses a GIS to combine several different datasets with a 2.5-dimensional calculation for the estimation volume. The method takes into account legislative, economical and geological limitations to aggregate extraction. This method is tested in the Helsinki Metropolitan area, the largest aggregate consumption area in Finland, and the results are compared to an earlier field study of rock aggregate resources.

Limitations of geology for rock aggregate production arise from local geological characteristics. In this study, these limitations consist of soil coverage and groundwater table level. Of these, soil coverage excludes deeply buried rock aggregate and groundwater level excludes rock below the groundwater table. Legislative limitations include built areas, conservation areas and large bodies of water, with buffer zone around, as well as outcrops deemed otherwise valuable, as all of these prohibit the extraction of aggregates

Using open data and open access tools is a topical choice as well as an economical one. Economically, the choice of using open data is an easy one. The data costs are nil, and the research could be easily replicated by a third party using the same data. This is also a valid argument for science, as the replication of results is an important step in an empirical sense. However, the quality and completeness of open data is often inferior to commercial data, and thus it would make sense to use that instead. My counter-argument to this is that even slightly inferior data may be used to garner valuable results. Indeed, it may often be more valuable to develop methods using less data, as there are cases where the available data is lacking in either quantity or quality. There may be cases where data is often lacking, and economical resources for both producing data and using commercial tools may be unfeasible. The topical argument for the use of open data and tools is simply the advancement of human progress. As knowledge is more often a commercial product, its use is always limited. However, this does not make sense for the advancement of science, as it will create competition instead of cooperation. Scientists may explore dead ends that another group may have already discovered, but not reported because of the commercial nature of scientific publishing. In a nutshell, open data use reduces the cost and thus the threshold of scientific inquiry.

The question posed in this study is: How to assess rock aggregate resources, using the $2.5 \mathrm{D}$ method, open data and open source tools? I present a model to answer this question, then evaluate this model by comparing it to previous studies on the matter and by field evaluations of the model's predictions.

\section{Data and methods}

\subsection{Study area}

In the year 2015, Finland used 118178 thousand metric tons of aggregates (Tilastokeskus, 2017). The test area for this study is the largest user area for them, the greater Helsinki Metropolitan area. This includes the municipalities of Helsinki, Espoo, Vantaa, Kauniainen, Kirkkonummi, Vihti, Järvenpää, Nurmijärvi, Hyvinkää, Kerava, Tuusula, 
Table 1. Data used in the study.

\begin{tabular}{|c|cccccc|}
\hline Data & Source & Name & Type & Datum & Accuracy & Copyright \\
\hline Exposed rock & GSF & Maalajit 1:50 000 & Polygon & 11.07 .16 & $1: 20000$ & Modified data 0 GSF 2016 \\
Elevation & NLS & Korkeusmalli 10m & Raster & 01.06 .16 & $10 \mathrm{~m}$ grid & CC/BY4.0/ NLS \\
Buildings & NLS & Maastotietokanta & Point, line, polygon & 01.06 .16 & $1: 20000$ & CC/BY4.0/ NLS \\
Roads & NLS & Maastotietokanta & Line & 01.06 .16 & $1: 20000$ & CC/BY4.0/NLS \\
Water & NLS & Maastotietokanta & Polygon & 01.06 .16 & $1: 20000$ & CC/BY4.0/NLS \\
Protection areas & SYKE & Suojelualueet & Polygon & 26.05 .16 & $1: 20000$ & CC/BY4.0/SYKE \\
Valuable outcrops & GSF & Arvokkaat kallioalueet & Polygon & 26.05 .16 & $1: 100000$ & CC/BY4.0/SYKE \\
\hline
\end{tabular}

Pornainen, Mäntsälä and Sipoo. The Helsinki area used $29 \%$ of aggregates used in Finland in 2014 (Lonka et al., 2015). The area also has a high percentage of competing land use, and therefore has more sterilized aggregate sources than other areas, making it an interesting test case. The study area is topographically heterogeneous, and exposed rock areas are concentrated on its northern, eastern and western parts as well as along the shoreline. Exposure is controlled by local geology, mainly the ice-scoured outcrops washed clean by the Baltic Sea. Along with glaciofluvial formations and marine clays, the scenery consists of plains bounded by eskers and jutting outcrops (Maunu, 1980; Laitala, 1991).

\subsection{Open data}

The Finnish government has decided to pursue an open access policy on publicly-funded data, and it is expected that such data finds uses in science as well as commercial applications. I utilized this kind of open access data for this study. In addition, all the work in this study is done on open-source computer programs, specifically on Quantum GIS (later QGIS) versions 2.8 and 2.18. While commercial computer programs would be available and often easier to work with, they are expensive and methods developed on open source are available to a larger base of users, especially those in developing countries.

\subsection{Methods}

This study uses open data from three different databases all produced by Finnish government agencies: The Geological Survey of Finland (GSF), The National Land Survey of Finland (NLS), and the Finnish Environment Institute (SYKE). The GSF data consist of exposed rock areas and 1:20000 scale bedrock mapping data. The NLS provides an elevation model as well as a basic topographic map, including the municipality borders. The SYKE data are environmental including data on inhabited areas, hydrology, nature conservation areas, groundwater production areas and land use plans. They are used to identify areas unsuitable for aggregate production. Table 1 gives the resolution, data type, source, datum and copyright information of each data set.

These data are used to create three separate map layers used in the analyses: the top and bottom surface layer of the resource estimate and the land use limitation layer. See Fig. 1 for the workflow of the model. The top surface layer is simply the elevation model, the upper limit of extraction. The bottom layer is the groundwater level, which is the lower limit of aggregate extraction in Finland. Groundwater level estimation uses point data for lakes, springs and sea level and line data for rivers. A network of points was extracted from these, and values for these points were assigned from the 


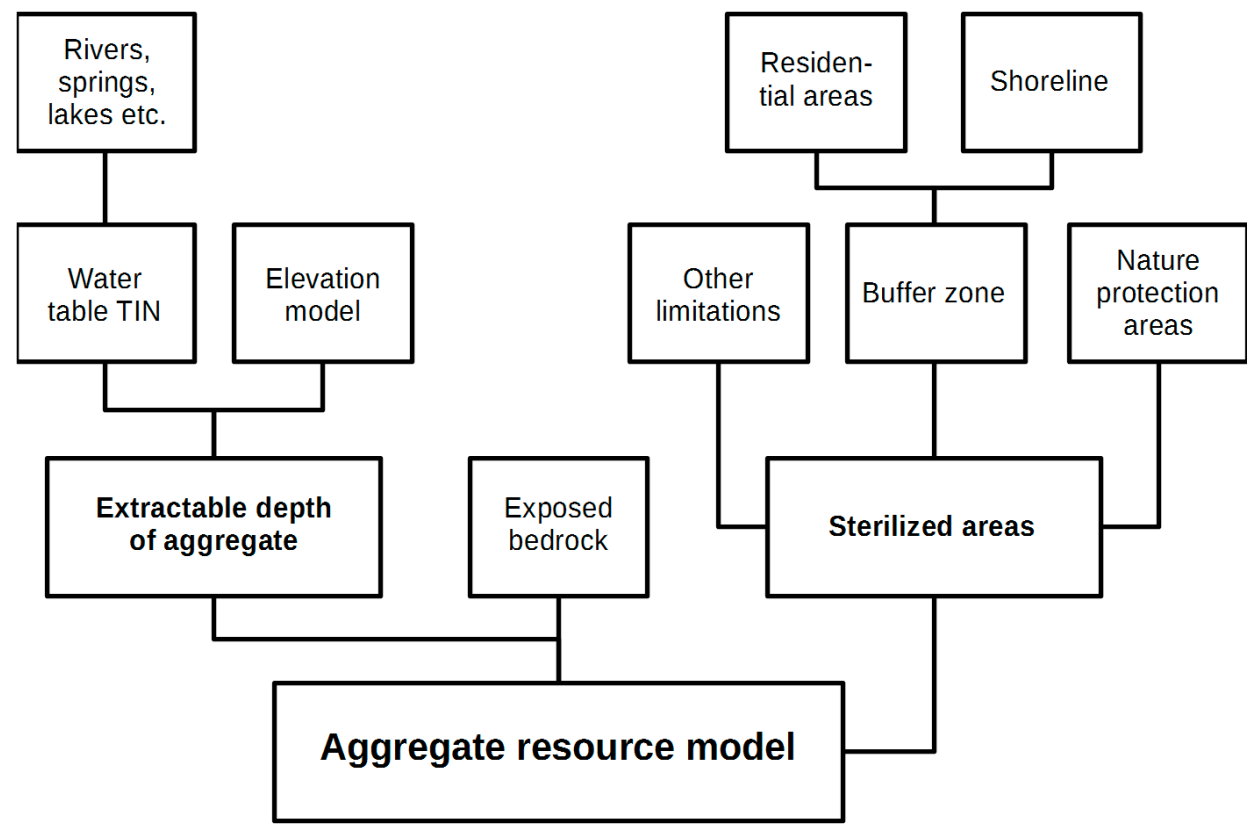

Figure 1. Workflow of the model.

elevation data. A triangulated irregular network (TIN) was calculated using this data. Finally, the groundwater level data is subtracted from the elevation data to produce a layer showing the thickness of the extractable layer.

The limitation layer is used to delineate and remove areas in which aggregate extraction is impossible. It consists of built areas, nature protection areas, military areas, previous claims, mines and quarries. All these are extracted from the NLS data and the SYKE data. A $500 \mathrm{~m}$ buffer zone is included in protected areas, rivers and the shores of major lakes, rivers and the sea. This buffer zone is set by Finnish legislation. A $300 \mathrm{~m}$ buffer zone is set around buildings and built areas, and a $150 \mathrm{~m}$ buffer around railroads and major roads, as legislators do not allow for quarry operation too near a major traffic lane. These buffer zones are set partly due to legislation, partly due to permit practices, as informed by discussions with industry stakeholders (Borén, pers. comm. 2016). In addition, only areas with ground cover of less than $1 \mathrm{~m}$ thickness are included in the estimate, again due to legislative restrictions. These are extracted from the GSF soil data set.

The resulting usable areas are then combined with the extractable thickness layer, and the result calculated by polygon. This calculation gives the amount of geologically available resource within each polygon, with an accuracy of a hundred cubic meters. As the product to waste ratio is not infinite, the actual amount of available aggregate is less than the given figure. As areas of less than 100000 cubic meters are unlikely to be economically viable, this accuracy is more than sufficient for the purposes of this model (Borén, pers. comm. 2016).

\subsection{Validation}

In addition to comparison with existing models, the accuracy of the model was tested by field observations. 24 locations were chosen from the 


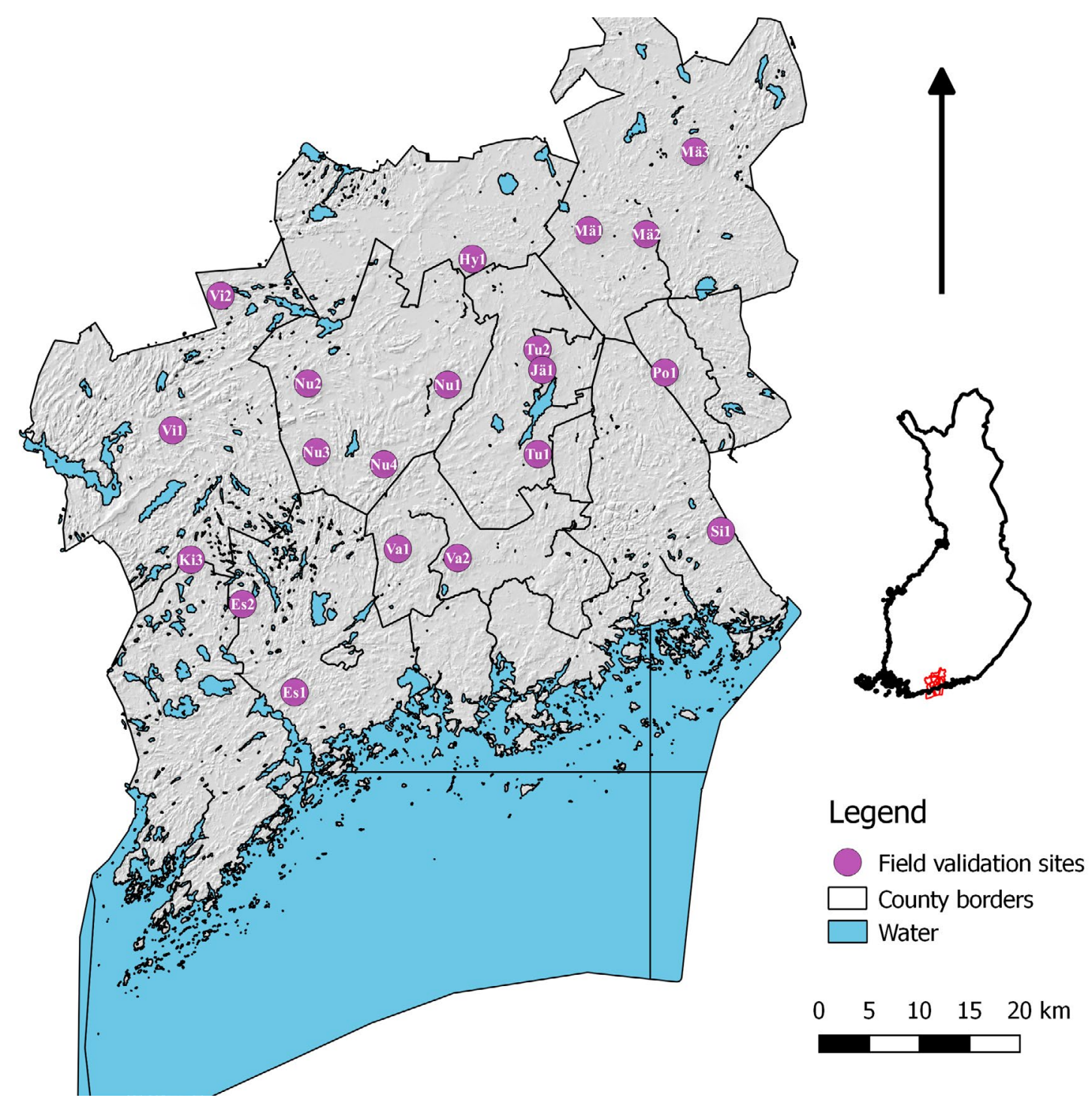

Figure 2. Study area and map of the field validation sites.

result at random, using the QGIS tool Random selection. Figure 2 shows the validation points. Each location was visited and observed for land use, vegetation, water features, rock type and possible other features affecting aggregate production. A photo was also taken from each site. The field validations were made on four different dates, in November 2016, April and May 2017. Each round of validations before the last provided valuable data which improved the model.

\section{Results}

The model predicts a large number of possible rock aggregate quarry sites. The total amount of possible rock aggregate resources is estimated as 1253 million $\mathrm{m}^{3}$. However, the spatial distribution of remaining aggregate locations is uneven (see Fig. 3). Large, usable sites are concentrated on the edges of the study area, because of the distribution 


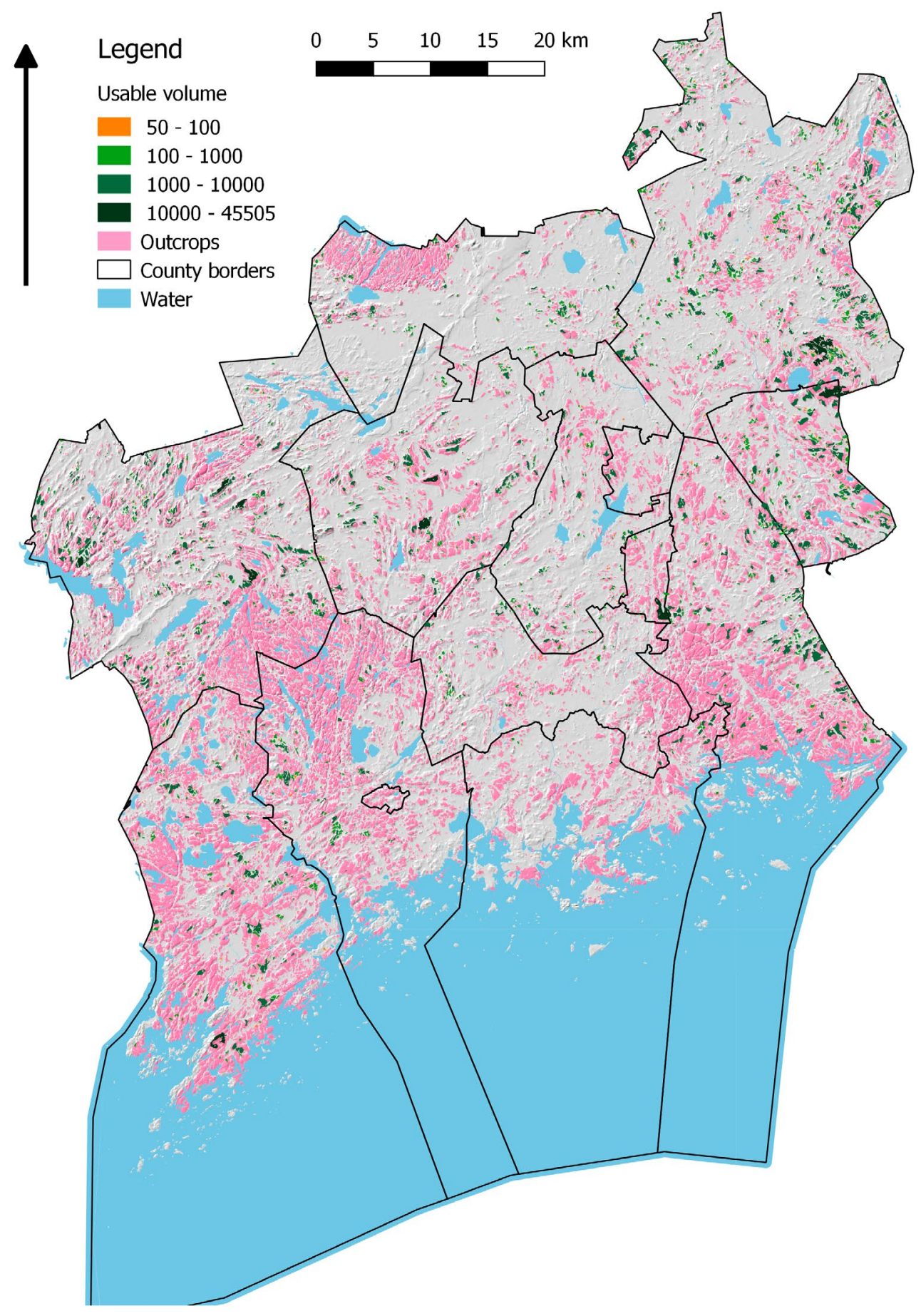

Figure 3. The map of available aggregate locations in the Helsinki region, as well as the expected depth of available resource. 
Table 2. The calculated available aggregate resources along with number of locations by municipality. The percentage of nature conservation area, number of inhabitants by square kilometer and percentage of exposed bedrock are shown for reference.

\begin{tabular}{|c|c|c|c|c|c|c|}
\hline County & Inhabitants & $\begin{array}{l}\text { Area (water not } \\
\text { included) }\end{array}$ & $\begin{array}{c}\% \text { of } \\
\text { outcrops }\end{array}$ & $\begin{array}{c}\% \text { of sterilized } \\
\text { area }\end{array}$ & $\begin{array}{l}\text { Aggregate } \\
\text { sites }\end{array}$ & $\begin{array}{c}\text { Extractable } \\
\text { aggregates (millions } \\
\text { of cubic meters) }\end{array}$ \\
\hline Espoo & 269802 & 312.22 & $0.0 \%$ & $99.07 \%$ & 91 & 40.18 \\
\hline Helsinki & 628208 & 214.21 & $0.0 \%$ & $99.41 \%$ & 41 & 1.56 \\
\hline Hyinkää & 46463 & 322.66 & $0.0 \%$ & $98.52 \%$ & 197 & 65.04 \\
\hline Järvenpää & 40900 & 37.54 & $0.0 \%$ & $100.00 \%$ & 0 & 0 \\
\hline Kauniainen & 9486 & 5.89 & $0.0 \%$ & $99.72 \%$ & 1 & 0.31 \\
\hline Kerava & 35293 & 30.63 & $0.0 \%$ & $99.44 \%$ & 19 & 1.72 \\
\hline Kirkkonummi & 38649 & 366.15 & $0.0 \%$ & $98.26 \%$ & 160 & 82.45 \\
\hline Mäntsälä & 20685 & 580.86 & $0.0 \%$ & $96.04 \%$ & 545 & 313.66 \\
\hline Nurmijärvi & 41897 & 361.86 & $0.0 \%$ & $99.51 \%$ & 70 & 38.28 \\
\hline Pornainen & 5125 & 146.52 & $0.0 \%$ & $92.81 \%$ & 136 & 187.05 \\
\hline Sipoo & 19399 & 339.63 & $0.0 \%$ & $96.44 \%$ & 180 & 262.88 \\
\hline Tuusula & 38459 & 219.5 & $0.0 \%$ & $99.33 \%$ & 62 & 23.03 \\
\hline Vantaa & 214605 & 238.36 & $0.0 \%$ & $98.99 \%$ & 94 & 40.74 \\
\hline Vihti & 28919 & 522.06 & $0.0 \%$ & $98.55 \%$ & 333 & 196.33 \\
\hline Total & 1437890 & 3698.09 & $0.0 \%$ & $98,29 \%$ * & 1929 & 1253.23 \\
\hline
\end{tabular}

of of sterilized area as seen in Table 2. This is as expected, due to the high percentage of urban land use in the area. The municipalities which use the greatest amount of aggregate (those with the highest population), are also those which have the greatest percentage of sterilized area. Thus, the areas with the highest need for aggregates have the least resources available, while the largest potential sites for production are all further away.

The model was validated by fieldwork. See Fig. 2 for the locations of the field validation sites. Table 3 shows the field observation data in condensed form. As seen from the table, all rock types were suitable for aggregate production, as could be expected from previous studies of the area (Maunu, 1980; Laitala, 1991; Grönholm, 2000a, 2000b; Vuokko, 2004). See Fig. $4 \mathrm{e}-4 \mathrm{~h}$ for the range of rock types.

No sites had water features other than spring runoff ditches, which would not affect aggregate production, the exception being site $\mathrm{Nu} 4$ (Fig. 4b), which had a stream running in the field next to it. Land use was in most cases forest, but in one case there were summer residences nearby and in 5 cases there was sparse habitation nearby. However, these sites were also far from aggregate use areas, and thus unlikely candidates for production areas, as the cost of aggregates dramatically increases over distance. The field validations were consistent with the model, with some exceptions (Fig. 4b-4d). One area was a highly visible and beautiful outcrop, which might not be easily used for aggregate as it is a scenic feature (Fig. 4d) and a quarry would likely meet strong opposition from residents. Another was an apparently unused forest, but there was evidence of unofficial use for motocross (see Fig. 4c). Finally, an area of highly usable rock was found at location Es3, but the location itself was close to the Nuuksio national park, which might affect the permits in the area. 

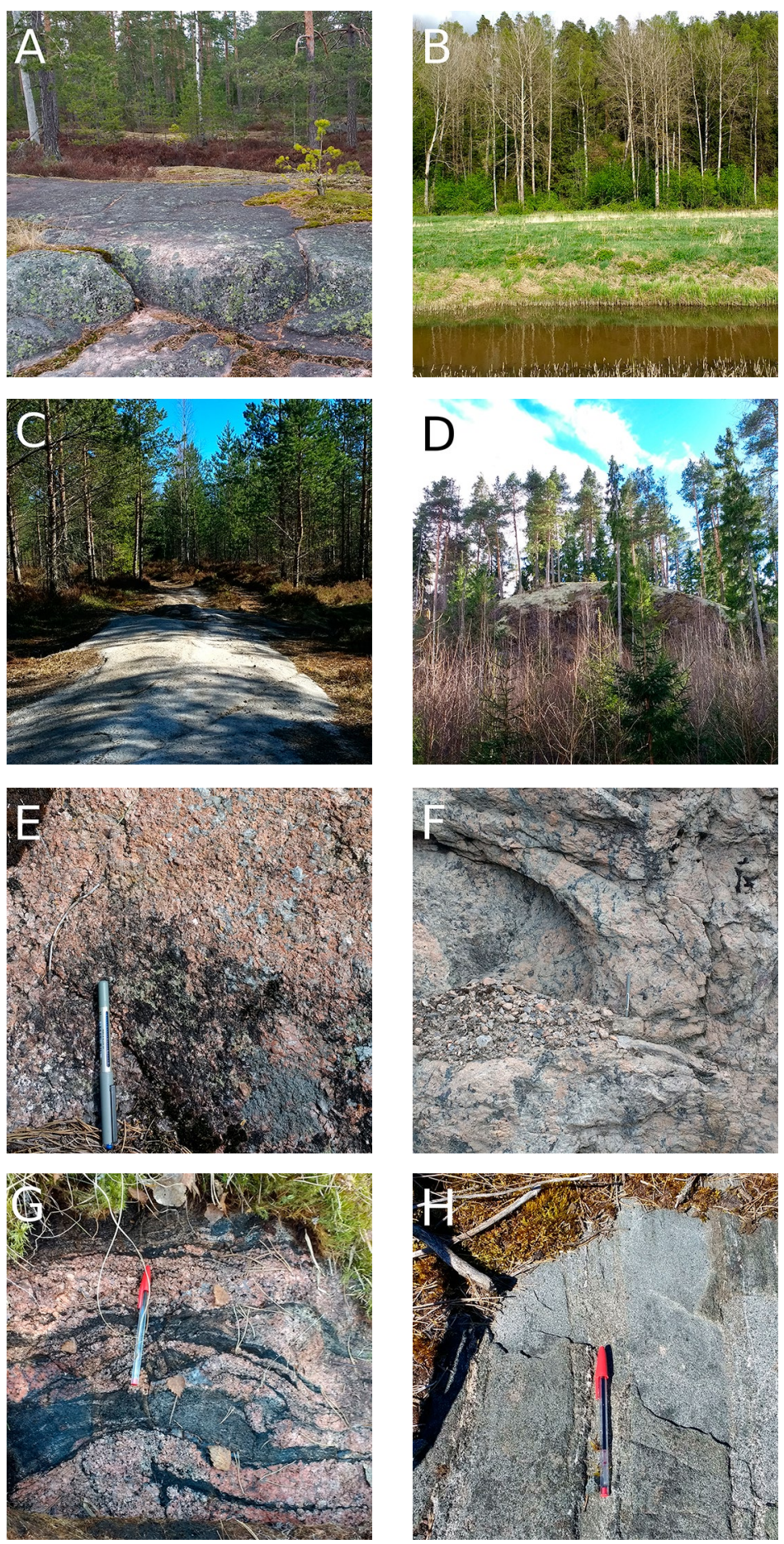

Figure 4. Questionable sites and the range of rock types encountered in the field validations. a) Outcrop at site Es3. A large well-exposed outcrop in a forested, little-used area, but near a national park. b) Stream at Nu4. Outcrop is at the edge of the woods. The stream is not large enough to affect the model. c) Outcrop at site Jä1. The site would synergize with the nearby landfill for aggregate production, but the area shows evidence of recreational use. d) Outcrop at Vi1. The outcrop is a prominent landmark. Should it be used for aggregates, the scenery would be drastically altered. e) Medium- to largegrained granite at Nu2. f) Migmatized granite at Va2. g) Granitic migmatite at Mä1. h) Mica gneiss at Mä2. 


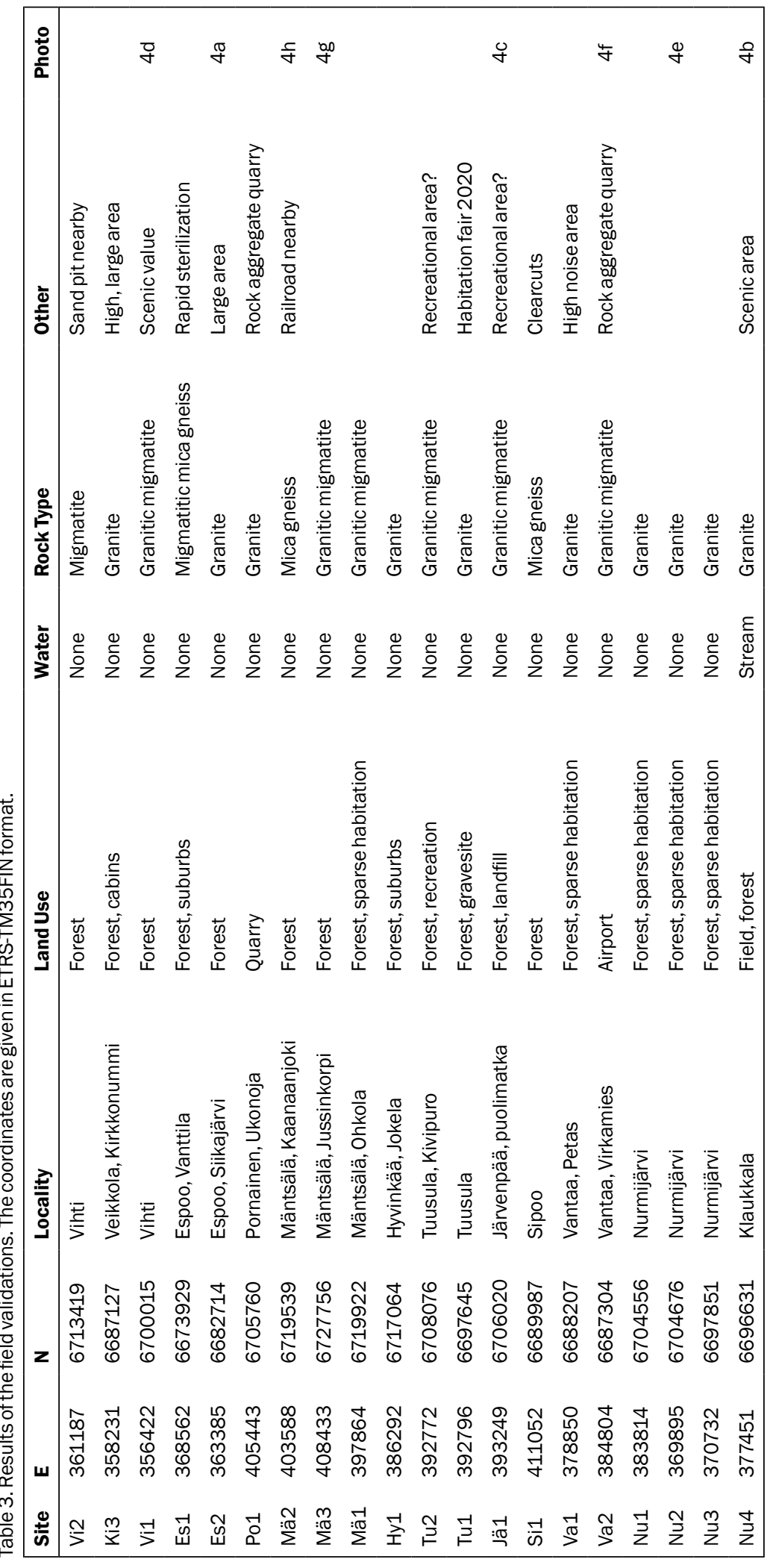




\section{Discussion}

\subsection{Value of the model}

The $2.5 \mathrm{D}$ model as it is in the current iteration works best as a tool for identifying prospective rock aggregate locations for further study and as a decision-making tool for planners. Previous field surveys by the GSF (e.g., Grönholm, 2000a, 2000b; Vuokko, 2004; Appelqvist et al., 2015) have focused on manually identified localities and evaluated their potential by laboratory testing, which is an expensive process and very important when high-quality aggregates are needed. The bulk of aggregates used in construction need not be of superior quality, and indeed the use of such rare resources should be restricted to projects that mandate their use. The majority of the local rocks are of high enough quality to be used in most projects (e.g., Vuokko, 2004). Thus, the bulk of used aggregates may be of lower grades, which are very common in the study area (quality classes are set by the Finnish Ministry of Transport and Communication).

\subsection{Accuracy and error control}

When using and especially when combining GIS data, the user must be well aware of error propagation and levels of uncertainty in the data used. The main sources for uncertainty in this model arise in two separate issues: elevation data and the groundwater model. First, the elevation data used has a set level of accuracy $\left(10 \mathrm{~m}^{2}\right)$. This sets the minimum area unit for volume estimation.

Second, the behavior of the groundwater table is not as simple in reality as it is in the model used. The current estimation is used in absence of a better model, and this issue will be addressed in a future version. Third, and perhaps most important is the reliability and accuracy of the data used. In general, the data is as up-to-date and accurate as possible, but as evidenced in the field studies, some changes have occurred since the data have been produced. These errors are due to rapid changes in the study area, and cannot truly be accounted for in a data-driven study such as this one. This underlines the need for field studies when planning an actual quarry site. Finally, combining data of differing resolutions, formats and from different eras requires control over all phases of the study. These are accounted for as outlined in the data chapter.

\subsection{Ethical issues}

Aggregate production is an area-intensive industry and produces pollution, mostly in the form of noise and dust (Smith \& Collis, 1993). This often causes conflict as residents and aggregate producers have competing interests (e.g. Bridge, 2000). For example, suitable sites for aggregate production may often be used by locals for recreational purposes as they are often areas of wilderness suitable for outings, camping et cetera. Therefore, aggregate production should be limited to as few sites as possible to minimize impact on local living conditions. In the producer's point of view, this is of course inconvenient, but concentrating efforts on fewer potential sites may reduce time and resources spent on permit procedures.

In addition, locations should be carefully considered to avoid loss or contamination of important cultural or natural sites (see Blades et al., 2007) Especially culturally relevant sites may not be recorded in any database that is used in determining possible locations, and therefore may not find their way into models such as this one. Thus, before making a decision, locals should be heard about possible sites of interest before any final decision.

In contrast, the availability of critical minerals should be safeguarded. For example, in the United Kingdom, different levels of planning policy take mineral safeguarding into consideration (see Wrighton et al., 2014) which attempts to ensure the availability of mineral production for the needs of society. In the case of aggregates, Finland has the POSKI program (see Appelqvist et al., 2015), but that is concerned only with the preservation of groundwater resources in contrast to aggregate 
production. A strategy (see Lonka et al., 2015) is prepared, but it appears that a nationwide policy should be applied.

\section{Conclusions}

The model presented here complements previous studies by focusing on rock aggregate resource location and quantity instead of quality. Therefore, the model focuses valuable expert work and reduces the time spent on locating possible aggregate resources. Its strength lies in the changing nature of urban areas; as demands and land use change, the model may be updated to reflect and analyze the present.

All previous studies have focused on searching for specific potential locations for aggregate production, and thus this study is the first of its kind to estimate the total available volume of rock aggregates in the area. The method is also usable for the estimation of aggregates in another area or of other widespread resources. Of course, both cases require the identification of the relevant limitations and local conditions. While it may be used in focusing search areas for prospective aggregate quarries, it is especially useful for policy and planning.

\section{Open questions and further research}

There are several areas in which the model may be improved. As it stands, it has proven to be of use, but it has its limitations in use and detail. There are two key components which would improve on

\section{References}

Appelqvist, S., Lindholm A., Nenonen N., Nurmi H., Sallasmaa O. \& Vänskä M., 2015. Pohjavesien suojelun ja kiviaineshuollon yhteensovittaminen Pirkanmaalla 20122015. Pirkanmaan POSKI-hanke. Pirkanmaan liitto 2015,302 p. the existing model greatly. First is the simplified groundwater model. As groundwater does not behave as a simple TIN of surface water points, its behavior should be more accurately modeled to reach a better accuracy. Second, the transportation network is a key component in both the pricing and the availability of aggregates. Its proximity and cost of transportation could be included in the model as positive indicators in aggregate accessibility. Both of these will be taken into account in the next iteration of this model.

Another direction of development is the use of this model in areas with less data available. An experiment of using this model for the evaluation of geological resources in such an area would be effective for the aforementioned use of this tool in developing countries worldwide. Such a model would of course require local expertise in geology, legislation and extraction practices, but it could be a valuable resource in an area with limited resources for mapping and discovering the best sources of local aggregates.

\section{Acknowledgments}

I would like to thank the City of Helsinki and K.H. Renlunds Stiftelse for their contributions to my work, as well as the NLS and the GSF for their generous policy on open data. I am also indebted to Dr. Petteri Muukkonen, Dr. Seija Kultti and Prof. Veli-Pekka Salonen of the University of Helsinki, as well as Dr. Saku Vuori at the Geological Survey of Finland. Thanks also to Mari Borén and her colleagues at Destia Oy for the opportunity to test the model. Finally thanks to my reviewers, whose comments improved the quality of this paper.

Baek, R., Heinrich, M. \& Letouzé-Zezula, G., 2003. GIS-based assessment of aggregates in Carinthia (Austria). Geologija 46/2,333-338.

Blades, N., Marchant, G. \& Greening, P., 2007. Impacts of Crushed Rock Quarries on Historic Villages and Cultural Landscapes. 
http://discovery.ucl.ac.uk/4845/1/4845.pdf (accessed 24.2.2017.)

Bobrowsky, P.T. \& Manson, G.K., 1998. Modeling sand and gravel deposits and aggregate resources potential. In: Bobrowsky, P.T. (ed.), Aggregate Resources, A global perspective. A.A.Balkema, Rotterdam, The Netherlands, pp. 231-254.

Bridge, G., 2000. The social regulation of resource access and environmental impact: Production, nature and contradiction in the US copper industry. Geoforum 31, 237-256.

https://doi.org/10.1016/S0016-7185(99)00046-9

Britschgi, R., 2001. Adjusting of groundwater protection and aggregate production. In: Kuula-Väisänen P. \& Uusinoka, R. (eds.), Proceedings of Aggregate 2001 - Environment and Economy (Helsinki 2001), Tampere University of Technology, Laboratory of engineering geology 51, 377380 .

Brown, T.J., 2012. Mineral potential mapping: a new spatial decision support tool for industry and planners. In: Hunger, E. \& Walton, G. (eds.), Proceedings of the 16th Extractive Industry Geology Conference, held at the University of Portsmouth 8th to 11th September 2010. Extractive Industry Geology Conferences Ltd, pp. 76-87.

Dahl, R., Wolden K., Erichsen, E., Ulvik A., Neeb P.-R. \& Riiber K., 2012. Sustainable management of aggregate resources in Norway. Bulletin of Engineering Geology and the Environment 71, 251-255. https://doi.org/10.1007/s10064-011-0397-0

Erichsen, E., Ulvik, A., Wolden, K. and Neeb, P.-R., 2008. Aggregates in Norway-Properties defining the quality of sand, gravel and hard rock for use as aggregate for building purposes. In: Slagstad, T. (ed.), Geology for Society, Geological Survey of Norway Special Publication 11, pp. 37-46.

Grönholm, S., 2000a. Kalliokiviainestutkimukset Uudellamaalla 1989-1999, osa I, yhteenveto. Geological Survey of Finland, archived report KA 51/99/2.

Grönholm, S., 2000b. Kalliokiviainestutkimukset Uudellamaalla, osa II, POSKI-projektin kalliokiviainestutkimukset Uudellamaalla 1989-1999 Geological Survey of Finland, archived report KA 51/99/1.

Härme, M., 1980. The general geological map of Finland, 1:400 000, Sheet C1-D1. (English summary). Geological Survey of Finland, Espoo, 96 p.

Karakaş, A., 2014. Defining the suitability of new crushed rock aggregate source areas in the North of Kocaeli Province using GIS. Bulletin of Engineering Geology and the Environment 73, 1183-1197. https://doi.org/10.1007/s10064-013-0557-5

Laitala, M., 1991. Helsingin kartta-alueen kallioperä. Summary: Pre-Quaternary rocks of the Helsinki map- sheet area. Geological Map of Finland 1:100000, Explanation to the maps of pre-quaternary rocks. Geological Survey of Finland, Espoo, 49 p.

Lonka, H. (ed.), Loukola-Ruskeeniemi, K. (ed.), Ehrukainen, E., Gustafsson, J., Honkanen, M., Härmä, P., Jauhiainen, P., Kuula, P., Nenonen, K. \& Pellinen, T., 2015. Kiviainesja luonnonkiviteollisuuden kehitysnäkymät. Työ- ja elinkeinoministeriön julkaisuja 54/2015.73 p.

Räisänen, M., 2004. From outcrops to dust -mapping, testing and quality assessment of aggregates. Academic dissertation, University of Helsinki. Publications of the Department of Geology D1, $14 \mathrm{p}$.

Räisänen, M. \& Torppa, A., 2005. Quality assessment of a geologically heterogeneous rock quarry in Pirkanmaa municipality, southern Finland. Bulletin of Engineering Geology and the Environment 64, 409-418. https://doi.org/10.1007/s10064-005-0006-1

Rintala, J., 2003. Maa-ainesten ottomäärät ja ottamislupatilanne 2002 - maa-aineslain mukaiset ottoalueet. Suomen Ympäristö 662, 62 p.

Robinson, G.R.Jr. \& Larkins, P.M., 2007. Probabilistic Prediction Models for Aggregate Quarry Siting. Natural Resources Research 16, 135-146. https://doi.org/10.1007/s11053-007-9039-4

Robinson, G.R.Jr., Kapo, K. E., \& Raines, G. L., 2004. A GIS analysis to evaluate areas suitable for crushed stone aggregate quarries in New England, USA. Natural Resources Research 13, 143-159.

https://doi.org/10.1023/B:NARR.0000046917. $21649.8 \mathrm{~d}$

Ross, I. K. \& Bobrowsky P.T., 2002. Aggregate potential mapping. In: Bobrowsky, P.T. (ed.), Geoenvironmental Mapping: methods, theory and practice, 1 st Edition. A.A. Balkema, Lisse, The Netherlands, pp. 195-222.

Smith, M.R. \& Collis L., 1993. Aggregates: Sand, Gravel and Crushed Rock Aggregate for Construction Purposes (2nd edition). Geological Society Engineering Geology Special Publication 9. Geological Society, London, $330 \mathrm{p}$.

Tilastokeskus, 2017. Suomen virallinen tilasto (SVT): Kansantalouden materiaalivirrat [verkkojulkaisu]. ISSN= 2242-1262. 2015, Liitetaulukko 1. Luonnonvarojen kokonaiskäyttö materiaaliryhmittäin 2006-2015. [viitattu: 24.2.2017].

Vuokko, J., 2004. Kalliokiviainestutkimukset Itä-Uudellamaalla ja Uudellamaalla 2004 -täydennyskartoitus. Geological Survey of Finland, archived report C/KA 51/04/1.

Wrighton, C.E., Bee, E.J. \& Mankelow J.M., 2014. The development and implementation of mineral safeguarding policies at national and local levels in the United Kingdom. Resources Policy 41, 160-170 https://doi.org/10.1016/j.resourpol.2014.05.006. 